\title{
Analysis on Female Workers Productivity among Buginese, Makassarese, and Torajanese Ethnic Groups In Small Industry Sector In Makassar City, South Sulawesi (Study In Food And Beverage Industry)
}

\author{
Aryati Arfah $^{1}$, M. Pudjihardjo ${ }^{2}$ \\ ${ }^{1}$ Faculty of Economics, Indonesia Muslim University, Indonesia \\ ${ }^{2}$ Faculty of Economics and Business, Brawijaya University, Indonesia
}

\begin{abstract}
This research aims to test and prove empirically: (1) whether individual characteristics, demographic factors, social-economic characteristics, work environment, and government policy have any impact on the productivity of female workers from Buginese, Makassarese and Torajanese ethnic groups in the food and beverage small industry sector in Makassar city; (2) whether there is any difference of productivity among those female workers. The population of this research includes all female workers in the food and beverage small industry sectors, consisting of 812 individuals. The sample of this research is 114 respondents. Sample is taken using simple random sampling method; and data are analyzed using multiple regressions. The findings of this research show that: (1) individual characteristics (health, tenure, work ethic), demographic characteristic (age), social-economic characteristic (wage) and work environment have significant impact on the productivity of female workers from the three ethnic groups in small industry sector in Makassar; meanwhile; demographic characteristics (number of dependant), social-economic characteristic (education), and government policy do not (2) there are significant differences in the productivity of female workers among the Buginese, Makassarese and Torajanese ethnic groups in the food and beverage small industry sectors in Makassar.
\end{abstract}

Keywords: productivity, female worker, ethnic groups, industry

\section{Introduction}

Workforce development as an integral part of national development program based on Pancasila and Constitution of Indonesia Republic 1945 is implemented to develop the human resource of Indonesia and develop the society of Indonesia to elevate the dignity, self-esteem, and pride of workers as well as to achieve wealthy, fair, and prosperous society both materially and spiritually [1].

Workforce has crucial role and important position as the actor to achieve development goal. Workforce development is aimed to enhance the quality of human resource and the contribution of the workforce both for the development and for achievement of right and interest guarantee based on the pride and dignity of humanity. Thus, workforce development aims to empower and utilize workforce optimally, create equality on the job opportunity, and labor supply that are consistent with the needs of the national development, as well as provide protection for labor to achieve welfare and enhance their prosperity including their family [1].

However, in reality, the potential of Indonesia workforce is not optimally empowered yet. It is due to the low productivity of Indonesia workers since some of the society members have low level of education or lack of training they obtain. This reality is reflected on the workforce composition in 2010. Based on the data, the education level of workers consists of 55.3 millions elementary school graduates and not-graduate from elementary school (51.5\%), 20.30 millions junior high school graduates (18.9\%), 15.63 million senior high school graduates $(14.5 \%), 8.34$ millions vocational school graduates (7.7\%), 2.89 millions diploma graduates (2.7\%), and only 4.94 millions bachelor graduates (4.7\%) [2].

A survey from Institute for Management of Development Switzerland in 2005 placed Indonesia worker's productivity to $59^{\text {th }}$ rank among 60 developed and developing countries. In 2007, based on the Ministry of Labor and Transmigration, the productivity of Indonesia workers was at the lowest rank among ASEAN countries. A report from ILO in 2010 mentioned that during the crisis in 2007 - 2009, workers productivity in ASEAN got worst, since in average, it experienced $0.3 \%$ decrease; yet, in China and India, it raised up reaching $8.7 \%$ and $4 \%$ respectively.

In line with the economics development of Indonesia, the number of worker gets enhanced, including female workers involvement. It was recorded in 2006, female workers who got job were only 48.08\%. In 2007, it became 50.25\%; and then, it reached 51.08\% in 2008. Moreover, it continued to develop as in 2009, it reached $51.77 \%$ [3]. The decision to enter the job market that should be taken by women is very complicated since they should be able to decide how much time they should allocate for working outside and for doing household 
matters per day, per week, or per month. The choice among those two activities is open for every individual as they are required to enhance their productivity in their workplace as well.

There are some factors influencing productivity level of workers such as education level, skill, discipline, attitude and work ethic, motivation, nutrition and health, income rate, social security, environment, work atmosphere, industrial relationship, technology, production facility, management, job opportunity, and achievement opportunity. Simanjuntak [4] adds three more factors influencing worker productivity. First, it is the quality and physical ability of the workers as measured by using education level, work experience, work motivation, work ethic, and physical health. Second, it is the supporting facility such as work environment and work condition. Third, it is supra facility such as industrial relationship and government policy.

Some research results from Bloom et.al. [5], Pindus et.al., [6], and Schultz [7] state that worker's health affects productivity and the payment that the worker receives. A healthier individual tends to be more physically energetic and psychologically more durable so that he/she will have smaller risk to experience things that burden/hinder him/her to work [8]. On the other hand, in a less-healthy condition, someone is still possible to work but at the lower level of productivity.

Other individual characteristic is about his/her tenure (period of employment). Hill (1990) in Liewelyn [9] mentions that tenure does not have significant influence on work productivity; meanwhile, Setiawati [10] and Budyani [11] find that tenure positively affects work productivity. This gap may occur due to the differences on the time and the object of the research.

Research from Budyani [11] finds that age has positive and significant effect on work productivity among female workers; it means that if the age is older, then the productivity is higher. It is different from what Liewelyn [9] has found as Liewelyn mentions that age has negative significant effect on productivity. Other variable that also influences productivity is the number of dependant. Some of the research results show that the number of dependant positively and significantly affects productivity [12]; yet, Troena [13] mentions that the number of dependant has indirect influence on productivity.

Blaug[14], Card [15], Cohn and Addison (1998) in Pandey [16] say that education has a role on the productivity enhancement [17]; it means that the higher the education level is, the better the productivity level will be. However, other researcher demonstrates that education does not have significant role on productivity [10], [12]. Further, wage rate also has positive and significant effect on productivity; yet, based on Troena [13], wage has indirect influence on the productivity enhancement. Other result exhibits that wage discrepancy between genders, which is higher in manufacturing industries at particular year, does not have any relationship with productivity enhancement for the next period of year [18].

Work environments that affect productivity enhancement among female workers are work condition, work relationship, and work facility that should be more considered to see their role on productivity. Troena's [13] and Semmaila's [12] findings show that work environment has positive and significant effect.

Other influencing factor is the government policy to protect worker's rights as the effort to provide security guarantee for workers such as wage protection system, social security, women care, health security, and safety of working that will enhance productivity and prosperity of workers.

Makassar as the capital city of South-Sulawesi Province has potential to develop its industrial subsector. Industrial sector, other than agriculture sector, development will elevate the workforce demand. The workforce demand in small, medium, and big industries sub-sectors in this region has the similar trend with the national level: high demand level but low productivity. Low level of productivity is due to its HRM quality. The quality and the skill of workers are influenced by the education level, job training, job motivation, and work ethic, as well as physical and psychological competences of the workers themselves. Based on the data [19], the education level of female workers is dominated by Elementary School dropped-out (not graduated from Elementary School) for 58.76\%. Other than education level, female workers who have working hours less than 35 hours per week are 50.27\%; while those who have more than 35 working hours per week are $49.73 \%$.

Another factor is that there is no national labor social security; it means that only a few number of the population will receive pension such as government officers (public servants) and some private sector labors. It is due to the lack of product benefit information that is issued by Jamsostek (Labor Social Security) since the weak coordination between PT. Jamsostek and local government (labor and transmigration department) of Makassar so that the business owner is in doubt to register their workers in that program.

Further, in Makassar, there are three ethnic groups such as Buginese, Makassarese, and Torajanese that are bounded to cultural identity called as "Siri". This culture rules how to behave in arranging social life that enables an individual to run his/her role based on the social position legitimated by the society [20]. Therefore, in the effort to enhance competitiveness, dynamics, and productivity, "Siri" must be deconstructed to be a work ethic so that the term of "Siri" is not only a name but also an encouraging spirit to achieve productivity enhancement [21]. Referring to that identification, the research objectives are: (1) to analyze the role of individual characteristic (health, tenure, work ethic), demography (age, number of dependant), social-economics (education, wage), work environment, and government policy on female workers productivity among Buginese, 
Makassarese, and Torajanese ethnic groups in small industry sector in Makassar city, and (2) to analysis the productivity gap among Buginese, Makassarese, and Torajanese ethnic groups in small industry sector in Makassar, South Sulawesi.

\section{Research Method}

This research was conducted in Makassar city in the Small Industries of Food and Beverage. The criteria of Small Business included in this research are those industries which have asset at most IDR 200,000,000 (two hundred millions rupiah) excluding land and building assets, and hire 5 to 19 employees including the business owner.

The population is all of the female workers in food and beverage small industry that counts as many as 812 people. To define the sample number, this research uses Slovin's formula [22]. The minimum number of sample obtained by using Slovin's formula is 114 people. The data collection is conducted by combining some methods such as observation and interview, as well as questionnaire distribution. The data analysis utilized in this research is multiple regression analysis.

\section{Results}

Table 1 demonstrates that female workers in small industry consist of 41 Buginese (36\%), 42 Makassarese (36.8\%), and 31 Torajanese (27.2\%). The difference in number occurs since the distribution of small industry in Makassar mostly is dominated by Makassarese ethnic group due to the most population of the residents in that city are Makassarese.

Table 1

Number of Respondents in Small Industry

based on the Ethnic Group in 2010

\begin{tabular}{|c|c|c|c|}
\hline Num. & Ethnicity & Frequency & Percentage \\
\hline 1 & Buginese & 41 & 36 \\
2 & Makassarese & 42 & 36.8 \\
3 & Torajanese & 31 & 27.2 \\
\hline \multicolumn{2}{r|}{ Total } & $\mathbf{1 1 4}$ & $\mathbf{1 0 0}$ \\
\hline
\end{tabular}

\section{Source: Processed Primary Data in 2010}

The health status of the female workers is measured by using the number of the days they are absent for sickness. The respondents who are absent due to sickness generally get only one day absent; and the most frequent ethnic group is Makassarese women for $28.1 \%$, followed by Buginese and Torajanese ethnic groups for $22.8 \%$ and $21.9 \%$ respectively. Two-days absent workers are only 12 respondents $(10.5 \%)$. The rest are those who are absent for 3 and 4 days in a month for $13.2 \%$ and $3.5 \%$ among research sample respectively.

The work tenure of female workers in small industry sectors is varied. Among 114 observed respondents, 41 Buginese who have $1-2$ years tenure are $18.4 \%, 42$ Makassarese ethnics who have $1-2$ years tenure are 24 respondents $(21.1 \%), 31$ Torajanese ethics who have $1-2$ tenure are 23 respondents $(20.2 \%)$. The respondents who have $3-4$ years tenure are $13.2 \%$; those who have $5-6$ years tenure are $0.9 \%$. The respondents who have more than 6 years tenure are 13.2\%; whereas those who have less than one year tenure are $13.2 \%$ as well. Among the three observed ethnic groups, Buginese are the most frequent group who have work tenure form than 6 years for $7.9 \%$, followed by Torajanese and Makassarese for $2.6 \%$ of each group. The dominant tenure is $1-2$ years for all of the ethnic groups. The work tenure of the respondents can be viewed in the Table 2 .

Table 2

Work Tenure of Respondents in Small Industry based on the Ethnic Group in 2010

\begin{tabular}{|c|c|c|c|c|c|c|c|c|c|}
\hline \multirow{3}{*}{ Num. } & \multirow{3}{*}{$\begin{array}{c}\text { Work Tenure } \\
\text { (Years) }\end{array}$} & \multicolumn{6}{|c|}{ Ethnicity } & \multirow{2}{*}{\multicolumn{2}{|c|}{ Total }} \\
\hline & & \multicolumn{2}{|c|}{ Buginese } & \multicolumn{2}{|c|}{ Makassarese } & \multicolumn{2}{|c|}{ Torajanese } & & \\
\hline & & f & $\%$ & f & $\%$ & $\mathbf{f}$ & $\%$ & $\mathbf{f}$ & $\%$ \\
\hline 1 & $<1$ & 5 & 4.4 & 8 & 7 & 2 & 1.8 & 15 & 13.2 \\
\hline 2 & $1-2$ & 21 & 18.4 & 24 & 21.1 & 23 & 20.2 & 68 & 59.6 \\
\hline 3 & $3-4$ & 6 & 5.3 & 7 & 6.1 & 2 & 1.8 & 15 & 13.2 \\
\hline 4 & $5-6$ & 0 & 0 & 0 & 0 & 1 & 0.9 & 1 & 0.9 \\
\hline 5 & $>6$ & 9 & 7.9 & 3 & 2.6 & 3 & 2.6 & 15 & 13.2 \\
\hline & Sum & 41 & 36.0 & 42 & 36.8 & 31 & 27.2 & 114 & 100 \\
\hline
\end{tabular}

Source: Processed Primary Data in 2010 
The sample distribution based on the respondent's age shows that most of the respondents who are at the age of $20-29$ years old are 20 people (17.5\%) of Buginese, 20 people $(17.5 \%)$ of Makassarese, and 18 people $(15.6 \%)$ of Torajanese. At the age of $30-39$ years old there are 32 people distributed in 8 people $(7 \%)$ of Buginese, 14 people (12.3\%) of Makassarese, and 10 people (8.8\%) of Torajanese ethnic. The $40-49$ years old respondents are 9 people; those who are 50-59 and more than 60 years old are 2 for each ethnic group. The most frequent age is at the productive age that affects the enhancement of female workers productivity.

At most, the number of family member is six people for each family at the average number of dependants are 2 people. The number of dependant indicates that the number of people in a family that a respondent responsible for. Number of dependant form 0 to 2 people in a family is 85 people (74.6\%); it consists of 28 Buginese (24.6\%), 29 Makassarese (25.4\%), and 28 Torajanese (24.6\%). Workers who have 3 dependants in their family are 5 respondents $(4.4 \%)$ consisting of 2 Buginese (1.8\%) and 3 Makassarese (2.6\%). Workers with 4 dependants are 8 respondents consisting of 6 Buginese (5.3\%) and 2 Makassarese (1.8\%). There are 16 female workers who have more than 5 dependants. The number of dependant is not only counted based on how many children they have but also the parents who live at the same house with them.

Respondent distribution based on the education level is showed in the Table 3.

Table 3.

Education Level of Respondents in Small Industry based on the Ethnic Group in 2010

\begin{tabular}{|c|c|c|c|c|c|c|c|c|c|}
\hline \multirow{3}{*}{ Num. } & \multirow{3}{*}{ Education Level } & \multicolumn{6}{|c|}{ Ethnicity } & \multirow{2}{*}{\multicolumn{2}{|c|}{ Total }} \\
\hline & & \multicolumn{2}{|c|}{ Buginese } & \multicolumn{2}{|c|}{ Makassarese } & \multicolumn{2}{|c|}{ Torajanese } & & \\
\hline & & $\mathbf{f}$ & $\%$ & $\mathbf{f}$ & $\%$ & $\mathbf{f}$ & $\%$ & $\mathbf{f}$ & $\%$ \\
\hline 1 & $\begin{array}{c}\text { Below or not } \\
\text { graduated from } \\
\text { Elementary School }\end{array}$ & 1 & 0.9 & 0 & 0 & 0 & 0 & 1 & 0.9 \\
\hline 2 & Elementary School & 10 & 8.8 & 20 & 17.5 & 7 & 6.1 & 37 & 32.5 \\
\hline 3 & Junior High School & 22 & 19.3 & 17 & 14.9 & 15 & 13.2 & 54 & 47.4 \\
\hline 4 & Senior High School & 6 & 5.3 & 5 & 4.4 & 8 & 7.0 & 19 & 16.7 \\
\hline 5 & Diploma/Bachelor & 2 & 1.8 & 0 & 0 & 1 & 0.9 & 3 & 2.6 \\
\hline & Sum & 41 & 36 & 42 & 36.8 & 31 & 27.2 & 114 & 100 \\
\hline
\end{tabular}

Source: Processed primary data, 2010

In Table 3, it implies that the education level of female workers in small industry sector is dominated by workers with junior high school graduate for 54 workers consisting of 22 Buginese (19.3\%), 17 Makassarese (14.9\%), and 15 Torajanese (13.2\%). It indicates that the percentage of female workers who have junior high school education among Buginese is higher than other ethnic groups. Female workers who are senior high school graduates are 19 people (16.7\%) consisting of 6 Buginese (5.3\%), 5 Makassarese $(4.4 \%)$, and 8 Torajanese $(7.0 \%)$. Those who hold bachelor degree are only 3 people $(2.6 \%)$.

As viewed from the wage rate obtained by female workers in small industry sector is dominated by the wage rate between IDR 500,000 to IDR 749,000 as it scores $68.4 \%$ from the total sample. Among that number, it consists of $25.4 \%$ Buginese, $26.3 \%$ Makassarese, and $16.7 \%$ Torajanese. Those who get more than IDR $1,500,000$ are only $4.4 \%$ which consist of $1.8 \%$ Buginese and $2.6 \%$ Makassarese. The average wage rate of female workers in small industry sector is IDR 794,315 rounded to IDR 800, 000.

The productivity level of female workers is measured by using the index number as the result of comparison between real production and standard production determined by the business owner. Based on the measurement result among those three ethnic groups, most of them score below 1 of productivity level. It means that the real production achieved by those workers is lesser than standard production determined by the organization. Those who get less than 1 productivity level are 89.5\% Buginese, 34.2\% Makassarese 25.5\% and Torajanese. However, those who have achieved more than 1 level of productivity which means that the obtained real production is higher than the standard production determined by the organization, Buginese ranks the first since the ethnic group scores $6.1 \%$, followed by Makassarese and Torajanese for $2.6 \%$ and $1.8 \%$ respectively.

The work ethic of female workers consists of 10 indicators; the 10 indicators has 1 to 5 scores unless for X3.4, X3.8, and X3.9 which has 2 to 5 scores. The score of X3.1 (hard working) is in the low category. It can be seen from the respondent's perception stating strongly disagree for stopping working hard if they have sufficient inheritance for seventh descendant; even they have that kind of inheritance, they will work still. The aim of those female workers to work is to reduce the responsibility load their husband has. In overall, the average score of work ethic is in high category; if it is related to ethnicity, it is presented in Table 4. 
Table 4

Work ethic of the Respondents in Small Industry based on the Ethnic Group in 2010

\begin{tabular}{|c|c|c|c|c|c|c|c|c|c|}
\hline \multirow{3}{*}{ Num. } & \multirow{3}{*}{ Work ethic } & \multicolumn{6}{|c|}{ Ethnicity } & \multirow{2}{*}{\multicolumn{2}{|c|}{ Total }} \\
\hline & & \multicolumn{2}{|c|}{ Buginese } & \multicolumn{2}{|c|}{ Makassarese } & \multicolumn{2}{|c|}{ Torajanese } & & \\
\hline & & f & $\%$ & $\mathbf{f}$ & $\%$ & f & $\%$ & $\mathbf{f}$ & $\%$ \\
\hline 1 & Quite High & 13 & 11.4 & 10 & 8.8 & 8 & 7.0 & 31 & 27.2 \\
\hline 2 & High & 22 & 19.3 & 26 & 22.8 & 21 & 18.4 & 69 & 60.5 \\
\hline 3 & Very High & 6 & 5.3 & 6 & 5.3 & 2 & 1.8 & 14 & 12.3 \\
\hline & Sum & 41 & 36.0 & 42 & 36.8 & 31 & 27.2 & 114 & 100 \\
\hline
\end{tabular}

\section{Source: Processed Primary Data, 2010}

Table 4 demonstrates that from the work ethic among three ethnic groups, Buginese, Makassarese, and Torajanese who show high work ethic are 69 respondents. It consists of 22 Buginese (19.3\%), 26 Makassarese $(22.8 \%)$ and 21 Torajanese $(18.4 \%)$. Next, those who have quite high work ethic are 31 respondents $(27.2 \%)$ consisting of 13 Buginese (11.4\%), 10 Makassarese $(8.8 \%)$, and 8 Torajanese $(7 \%)$; furthermore, those who have very high work ethic are 14 respondents $(12.3 \%)$ consisting of 6 Buginese $(5.3 \%)$, 6 Makassarese $(5.3 \%)$ and 2 Torajanese $(1.8 \%)$.

Work environment includes 4 indicators. The indicator X8.1 has 1 to 5 scores. It proves that some of the workers feel that their workspace is too narrow with hot temperature, eventhough the percentage is only $0.9 \%$. Further, X8.2, X8.3, and X8.4 have 3 to 5 scores and get 3.95, 4.01, and 3.84 average score for each indicator respectively. In general, the average score of work environment is good; it implies that work environment is highly supporting the productivity enhancement of the workers. Work environment as related to the three ethnic groups (Buginese, Makassarese, and Torajanese) can be seen in the Table 5.

Table 5

Perception of Respondents on Work Environment in Small Industry based on the Ethnic Group in 2010

\begin{tabular}{|c|c|c|c|c|c|c|c|c|c|}
\hline \multirow{3}{*}{ Num. } & \multirow{3}{*}{$\begin{array}{c}\text { Work } \\
\text { Environment }\end{array}$} & \multicolumn{6}{|c|}{ Ethnicity } & \multirow{2}{*}{\multicolumn{2}{|c|}{ Total }} \\
\hline & & \multicolumn{2}{|c|}{ Buginese } & \multicolumn{2}{|c|}{ Makassarese } & \multicolumn{2}{|c|}{ Torajanese } & & \\
\hline & & $\mathbf{f}$ & $\%$ & $\mathbf{f}$ & $\%$ & $\mathbf{f}$ & $\%$ & $\mathbf{f}$ & $\%$ \\
\hline 1 & Quite Good & 2 & 1.8 & 1 & 0.9 & 0 & 0.0 & 3 & 2.6 \\
\hline 2 & Good & 33 & 28.9 & 29 & 25.4 & 23 & 20.2 & 85 & 74.4 \\
\hline 3 & Very Good & 6 & 5.3 & 12 & 10.5 & 8 & 7.0 & 26 & 22.8 \\
\hline & Sum & 41 & 36.0 & 42 & 36.8 & 31 & 27.2 & 114 & 100 \\
\hline
\end{tabular}

Source: Processed Primary Data, 2010

Respondents perceive that they have good work environment as seen from 85 (74.4\%) respondents who express this perception; it consists of 33 Buginese (28.9\%), 29 Makassarese (25.4\%), and 23 Torajanese (20.2\%). The other 26 respondents mention that they have very good work environment; meanwhile the rest 3 respondents state enough work environment. In average, respondents' perception on their work environment is good for all ethnic groups.

Government policy includes 8 indicators; The X9.1, X9.2, X9.3, X9.7 and X9.8 obtain scores from 1 to 5; meanwhile, the indicator of X9.4, X9.5, and X9.6 get the scores from 2 to 5. In overall, the respondents' perceptions agree. It shows that those workers agree if their organization workplace implements government policy as the effort to enhance workers productivity. Based on each ethnic group, the respondents' perception on the government policy can be observed in Table 6

Table 6

Perception of Respondents on Government Policy

In Small Industry Based on the Ethic Group in 2010

\begin{tabular}{|c|c|c|c|c|c|c|c|c|c|}
\hline \multirow{3}{*}{ Num. } & \multirow{3}{*}{$\begin{array}{c}\text { Government } \\
\text { Policy }\end{array}$} & \multicolumn{6}{|c|}{ Ethnicity } & \multirow{2}{*}{\multicolumn{2}{|c|}{ Total }} \\
\hline & & \multicolumn{2}{|c|}{ Buginese } & \multicolumn{2}{|c|}{ Makassarese } & \multicolumn{2}{|c|}{ Torajanese } & & \\
\hline & & $\mathbf{f}$ & $\%$ & $\mathbf{f}$ & $\%$ & $\mathbf{f}$ & $\%$ & $\mathbf{f}$ & $\%$ \\
\hline 1 & Disagree & 1 & 0.9 & 2 & 1.8 & 2 & 1.8 & 5 & 4.4 \\
\hline 2 & Quite Disagree & 2 & 1.8 & 6 & 5.3 & 4 & 3.5 & 12 & 10.5 \\
\hline 3 & Agree & 14 & 12.3 & 28 & 24.60 & 16 & 14.0 & 58 & 50.9 \\
\hline 4 & Strongly Agree & 24 & 21.1 & 6 & 5.3 & 9 & 7.9 & 39 & 34.2 \\
\hline & Sum & 41 & 36.0 & 42 & 36.8 & 31 & 27.2 & 114 & 100 \\
\hline
\end{tabular}

Source: Processed Primary Data, 2010

Table 6 shows that commonly the three ethnic groups (Buginese, Makassarese, and Torajanese) agree if the government policy is applied in the organization they work. There are 58 respondents who express their agreement by stating that they agree; furthermore, 39 respondents state that they strongly agree. Those who disagree are only 4.4\%; their disagreement is related to the minimum wage rate because they demand for 
sufficient wage rate to fulfill their minimum physical needs.

Analysis on some factors that influence female workers productivity uses multiple regression analysis. The variables inserted in the regression model are individual characteristics (health, tenure, and work ethic), demographical characteristics (age, number of dependant), social-economics variable (education and wage rate), work environment, and government policy. Testing the hypothesis of the variables that affect female workers productivity as the main focus of this research utilizes the regression coefficient that is presented in the Table 7 .

Table 7

Regression Coefficient That Defines

Female Workers Productivity in Small Industry Sector

\begin{tabular}{|c|c|c|c|c|c|c|c|}
\hline \multirow[t]{2}{*}{ Variable } & \multicolumn{2}{|c|}{$\begin{array}{l}\text { Unstandardized } \\
\text { Coefficients }\end{array}$} & \multirow{2}{*}{$\begin{array}{c}\begin{array}{c}\text { Standardize } \\
\text { Coefficient }\end{array} \\
\text { Beta } \\
\end{array}$} & \multirow[t]{2}{*}{$\mathbf{t}$} & \multirow[t]{2}{*}{ sig } & \multirow[t]{2}{*}{$\mathbf{F}$} & \multirow[t]{2}{*}{ sig } \\
\hline & B & STD Error & & & & & \\
\hline Constant & 0.428 & 0.073 & & 5.871 & 0.000 & 35.669 & 0.000 \\
\hline X1 & -0.026 & 0.004 & -0.342 & -6.132 & 0.000 & & \\
\hline $\mathrm{X} 2$ & 0.0003 & 0.000 & 0.0125 & 2.394 & 0.018 & & \\
\hline X3 & 0.056 & 0.015 & 0.246 & 3.670 & 0.000 & & \\
\hline $\mathrm{X} 4$ & 0.003 & 0.001 & 0.237 & 2.658 & 0.009 & & \\
\hline $\mathrm{X} 5$ & 0.00008 & 0.004 & 0.001 & 0.019 & 0.985 & & \\
\hline X6 & 0.004 & 0.002 & 0.088 & 1.661 & 0.100 & & \\
\hline X7 & 0.0000 & 0.000 & 0.240 & 3.362 & 0.001 & & \\
\hline X8 & 0.045 & 0.017 & 0.144 & 2.621 & 0.010 & & \\
\hline $\mathrm{X} 9$ & 0.001 & 0.008 & 0.005 & 0.099 & 0.921 & & \\
\hline \multirow{6}{*}{\multicolumn{2}{|c|}{$\begin{array}{c}\mathrm{R} \\
\mathrm{R}-\mathrm{Squared} \\
\text { Adjusted R }- \text { Squared } \\
\mathrm{F} \text { table } \\
\mathrm{T} \text { table } \\
\alpha\end{array}$}} & 0.869 & \multirow{6}{*}{\multicolumn{2}{|c|}{$\begin{array}{c}\text { Std Error of The Estimate } \\
\text { DW }\end{array}$}} & & \multirow{6}{*}{\multicolumn{2}{|c|}{$\begin{array}{c}0.06177 \\
1.640\end{array}$}} \\
\hline & & 0.755 & & & & & \\
\hline & & 0.734 & & & & & \\
\hline & & 1.971 & & & & & \\
\hline & & 1.983 & & & & & \\
\hline & & 0.05 & & & & & \\
\hline
\end{tabular}

Description:

$\mathrm{X} 1=$ Health (number of absent days)

$\mathrm{X} 2$ = tenure (year)

$\mathrm{X} 3=$ Work ethic (the indicator's average score)

$\mathrm{X} 4$ = Age (year)

$\mathrm{X} 5$ = Number of Dependant (people)

$\mathrm{X} 6=$ Education (year)

$\mathrm{X} 7$ = Wage Rate (Rp/IDR)

$\mathrm{X} 8=$ Work Environment (the indicator's average score)

X9 = Government Policy (the indicator's average score)

The adjusted $\mathrm{R}^{2}$ is 0.734 or $73.4 \%$; it means the $73.4 \%$ of the occurring variance in productivity is explained by health, tenure, work ethoc, age, number of dependant, education, wage, work environment, and government policy. The statistical $\mathrm{F}$ test shows 35.669 value at $0.000(p<0.05)$ level of significance; it is concluded that at the standard error of $\alpha=0.10, \alpha=0.05$ or $\alpha=0.01, \mathrm{H}_{0}$ is rejected. It indicates that all of the independent variables are proper to explain the dependent variable. Health, tenure, work ethic, age, number of dependant, education, wage, work environment, and government policy variables simultaneously are able to explain or influence productivity variable. The estimation result of the regression equation has been partially tested using t-test at $\alpha=0.05$; it is revealed that partially there are 6 independent variables affecting significantly the female workers productivity such as X1 (health), X2 (tenure), X3 (work ethic), X4 (age), X7 (wage rate), and $\mathrm{X} 8$ (work environment); whereas, the variables that do not have significant influence on productivity are X5 (number of dependant), X6 (education level), and X9 (government policy).

\section{Discussion}

\subsection{The Role of Health on the Productivity of Female Workers}

The health of female workers is measured based on their leave or absent due to sickness. The regression result demonstrates significant value of health level $0.000<0.05$. The data analysis result shows that there is a significant relationship between health status and productivity of female workers. Good health will enhance productivity. This finding is amplified by Suma'mur [23] who mentions that physical and psychological healths are the critical support for productivity enhancement of a worker. Nutrition is one of the 
requirements to achieve good health level; therefore, nutrition refinement has crucial meaning to make healthier, smarter and higher performance productivity among workers. Sumarsono [24] states that nutrition enhancement at the health sector would decrease the level of sickness. Simanjuntak [25] mentions that the more practical way to enhance nutrition fact among industrial workers is by enhancing wage system to be able to fulfill their basic needs including their minimum nutrition need.

This result is consistent with the finding of Pindus et.al., [6], Schultz [7], and Bloom et.al, [5] who, at their research, mention that health affects productivity; it means that the better someone's health is, the higher the productivity he/she achieves. Conversely, if the health decreases, someone's productivity will also make the same direction. Knapp [26] finds that net nutrition in the first 20 years will positively and significantly influences productivity among workers in $20^{\text {th }}$ century. He also assumes causal relationship between nutrition and education.

\subsection{The Role of Tenure on the Productivity of Female Workers}

The statistical test result demonstrates that tenure affects significantly on the productivity of female workers from Buginese, Makassarese, and Torajanese ethnic groups. This finding can be interpreted that longer tenure will make them more skillful in handling their job so that they will produce higher output as their productivity gets enhanced.

The most frequent work tenure is $1-2$ years as it gets $59.6 \%$ of the total respondents. This finding is in resemblance with Ehreberg and Smith's [27] statement that female workers have fewer working hour than males for particular job; thus, female workers obtain fewer experience, even cut-off experience. It is also supported by Hasimoto and Raisin [28] who mention the same tone in their research by utilizing some variables such as seniority, work experience, age, education, and labor union. Their research finds that all of the variables have significant and positive effect on wage rate and productivity enhancement. Field and Wolff [29] who find that work tenure affects work experience mention that work experience will improve worker's skill which means that they will be more skillful in handling the similar job so that it affects their productivity as well.

\subsection{The Role of Work Ethic on the Productivity of Female Workers}

Work ethic affects productivity enhancement of female workers. From the statistical test result, it obtains the level of significance 0.000 which is less than 0.05 . This finding implies that the higher the work ethic of the female workers, then their productivity will improve also; conversely, if it decreases, then the productivity will lessen as well. Female workers have high productivity. Based on the observation, female workers there are $60.5 \%$, who have high productivity, $12.3 \%$ who have very high productivity, and the rest who are quite high. The female workers who have high productivity $12.3 \%$ are Makassarese followed by Buginese and then Torajanese. The discrepancy on the work ethic is due to the different interpretation on the term "Siri" in their culture among those three ethnic groups. Buginese and Makassarese, particularly for females, are bounded in a perspective that sees women's role limited merely to household matters since they are perceived to have physical and psychological weaknesses. To help their household's economics, Buginese, Makassarese, and Torajanese women still have high work ethic. This finding is supported by Ahmadin [30] who mentions that siri is valuable and crucial, so that the existence of life in that social system is defined by siri. In the social system of Buginese, Makassarese, and Torajanese, siri has been broadly interpreted related to various aspects of life; basically, siri is willingness to do kindness for themselves and among people to enhance their pride and dignity. For Torajanese, siri is a social norm related to self-esteem or particularly to responsibility on the self-respect as human. Based on the traditional view, pride and dignity of a man in their social life are observed and measured by using their spirit and effort to involve in solidarity and unity. This is manifested in the form of kinship cooperation, mainly during the funeral ceremony by sacrificing livestock and treasury that is possibly viewed as an extravagance for other people since it takes abundant cost. Therefore, Torajanese always focuses on hard working spirit [31].

\subsection{The Role of Age on the Productivity of Female Workers}

Generally, age is measured as they were born until the research is conducted. The respondent's age mostly is between $20-29$ years old. It shows that female workers are in the productive age when the research is conducted. If based on the ethnicity, Makassarese is the most at the age of $20-29$ years old. The statistical analysis demonstrates that age affects positively and significantly the female workers productivity. This finding indicates that the older a worker is, the more productive she will be as she has longer tenure, more skilful, and able to accomplish a job at relatively shorter time. This results is different from Smith's [32] finding which shows that by using micro approach linearly, it is found that age does not influence the working hour (tenure) significantly; whereas, by using macro approach, the role of age on working hour (tenure) is very significant as they obtain more working hour when their age gets older; and then, gradually the working hour will decrease as they get older which in turn will reduce their productivity. 


\subsection{The Role of Number of Dependant on the Productivity of Female Worker}

This study reveals that in small industry, female workers who have dependant from 0 to 2 are $55.3 \%$. As seen from the ethnic group, most of Makassarese have the number of dependant ranging from $0-2$ people and also more than 5 people. The data analysis result indicates that the number of dependant does not significantly influence female worker productivity. From the interview result with some of the female workers, it reveals that most of them have their parent as one of the dependants since generally they live at the same house with their parent. Poerwandari's [33] finding shows that married women commonly live with their parents at the same house. Other finding demonstrates that most of the research respondents have little children that are at the pre-school age. It will affect their working discipline since there will be a conflict between household responsibility and task at the workplace. The number of dependant influences the time allocation in workplace and time utilization in household matters. The more children and more dependant they have will reduce the time allocation for working and leisure (spare time, refreshing) which in turn will affect the working hour while the allocation for household matters tend to increase.

This finding is different from Wilbert's [34] research which mentions that a worker will feel hard as they have more dependants. The more dependants they have, they are demanded to work harder as their effort to enhance their productivity; it means that their workload will be higher whenever they have more dependants to support. Siagian [35] also states that if someone has higher number of dependants, then his/her productivity will be elevated as high as possible to obtain more reward.

\subsection{The Role of Education on the Productivity of Female Workers}

Education is one of the crucial factors in the human resource development. Education does not only improve knowledge but also skill. Education will enhance work productivity [4]. The result demonstrates that the most dominant education level among female workers in small industry sectors is junior high school graduate for $42.1 \%$ followed by elementary school graduate for $33.3 \%$. This finding reveals that education does not have any significant influence on the productivity enhancement. The interview result with some of the female workers shows the reason why they do not continue their education. It is due to no financial support; besides, their parents perceive that women do not need to take high education level as elementary school or junior high school is enough. They will have an arranged married after graduating from the school either elementary or junior high school.

This result is on the contrary to the Becker's finding [17] which mentions that education is related to the workers productivity since it can stimulate both cognitive and non-cognitive skills such as attitude, value, and behavior that are considered as positive matters. Ekelund and Hebert [36] as well as Ehrenberg [37] state that education level basically reflects the ability level of a worker. Better education means better productivity. This research also differs from Choudhry [38] who examines the factors that affect worker productivity in 40 countries that represent 4 groups of different income. This research finds that the productivity and income differences are due to the education level discrepancy; thus, it concludes that education level has positive and significant effect on worker productivity enhancement.

\subsection{The Role of Wage on the Female Workers Productivity}

Wage is functioned as the guarantee of income in the form of cash for workers and a guarantee of the production activity sustainability for organization; further, it will guarantee the profit generating process as the revenue of the business organization or the employer. It is in resemblance with the Sumarsono's [39] statement that wage is basically is the main resource of income; therefore, wage must be sufficient to fulfill their common needs (the worker and their family). The commonness of wage sufficiency can be seen and measured from the basic physical needs. This research finds that wage rate brings positive and significant effect on productivity enhancement. This finding can be interpreted that the higher the wage is, the productivity will be higher as well; yet, if the wage rate is low, then those workers will be less-motivated to enhance their productivity.

This finding is supported by the statement from Todaro and Smith [40] mentioning that female worker wage is lower than male's; moreover, it is hard to find a job that pay higher for women. Thus, female workers get stuck in a low-paid job. It implies that those female workers must work at a sector which does not implement the regulation and policy of minimum wage rate yet; even, they have to work at a sector that the employers does not provide social benefit/allowance and sufficient work safety for their workers. This finding is also supported by Sumarsono's [39] finding which says that to enhance the ease of work, efficiency, and organization sustainability, business owners need to guarantee the sufficient wage that is proper with the contribution of the workers. This research is in line with Grajek's [41] and Keane \& Prasad's [42] research which show that female workers who hold diploma degree obtain $45.5 \%$ higher wage than those who only take elementary school level. The wage rate of female workers tends to be lower than males wage rate. 


\subsection{The Role of Work Environment on Female Workers Productivity}

From the statistical test, work environment gets 0.010 level of significance. It implies that work environment has positive and significant role. Good or suited work environment makes workers work optimally, healthy, and comfortably. Work environment includes four indicators such as work condition, work relationship both with peer workers and with the employer, and work facility. A less-comfortable work environment, such as narrow room, hot temperature, and unguaranteed security, drives work productivity. Respondents' perception on their work environment shows that only 9 respondents $(7.9 \%)$ who mention that their work environment is not good; whereas, 55 respondents (48.2\%) express that their work environment is good. Bad work condition is indicated by the factual finding in the workplace as there are some small industries which do not pay attention on the workers' comfort as they provide too narrow room and hot temperature. It bothers workers' comfort so that their performance decreases and becomes less-productive. More than half workers (57.9\%) state that they have good relationship with their leader/supervisor. Good relationship does not mean a relative or kinship relationship but a rational economics-based relationship. This good relationship is implied with the equal treatment from the leader/supervisor on one worker and another without discriminating them based on the personal relationship. Peer workers relationship is generally good as well. From the obtained answers in the distributed questionnaire, 81 respondents $(71.1 \%)$ confirm good relationship among peer workers. Those workers should arrange teams which make them cooperate in good relationship to achieve good team result. Team work form is manifested into good cooperation and partnership. Further, there are 74 (64.9\%) respondents who mention that they have good work facility. Good facility will ease their work which in turn enhances productivity.

This result is also supported by Sedarmayanti [43] who mentions that human resource can wellestablish their activity so that he/she is able to achieve optimum result if he/she is supported by fit work environment. Work environment is perceived to be a good environment if those workers who work at that workplace can conduct their activities optimally, healthy, secure, and comfortable. Not-matched work environment will result on bad effect in long term period; furthermore, a not-good work environment demands more effort and time and does not support the attainment of efficient work system design.

\subsection{The Role of Government Policy on Female Workers Productivity}

Government policy in this research is related to wage protection and social security. This finding shows that government policy does not significantly affect productivity enhancement. This finding implies that in small industry sector, government policies for wage protection are (1) minimum wage rate as regulated in Article 88 92 Undang-Undang (Legislation) No. 13 2003, (2) working hours as regulated in Article 78 Undang-Undang No.13 2003, (3) recess and leave as well as wage protection are regulated in Article 79 Undang-Undang No.13 2003 which means that during menstrual period and sickness, giving birth, and breast-feeding time range, female workers will not do productive activity but obtain wage based on the applicable law before the implementation.

Social security is also not yet implemented so that those workers feel worried about job certainty whenever there is something risky happening on them. Social security is regulated in Article 99 UndangUndang No. 132003 which mentions that each workers has his/her right to get employment social security. Employment security program implemented by the government is mandatory for business organization to implement when the organization has fulfilled the requirement as it has at least 10 or more workers. Workers in small industry have not joined employment social security since the industry has not fulfilled the predetermined requirement to allocate some of its financial sources to Jamsostek (Jaminan Sosial Tenaga Kerjal Labor Social Security) program as an evidence of their participation in Jamsostek program. It is related to the characteristic of small industry that faces constraint in their limited capital and limited scope of production scale. This finding is supported by Abraham's opinion [44] which mentions that offering insurance or social security on those workers requires huge capital resources from their workplace. Organization should bear costs to establish health system, as well as premium cost to pay the insurance premium provided for the employees. The costs that an organization should bear are varied based on the job characteristic.

\subsection{Productivity Difference among Buginese, Makassarese, and Torajanese Female Workers}

Based on the statistical test, the $\mathrm{F}$ value is 4.671; it reveals significant difference on the productivity of female workers among the three ethnic groups. This gap is due to the different interpretation of each ethnic on their job. Makassarese has hard working, persistence, and never giving up attitude. A proverb of Makassarese says "Bajikangngang ngi mate cera'ka na mate cipuru" which means that better to die in pride than die in poverty. It confirms that Makassarese tends to work hard to ensure their life sustainability.

Buginese focuses more on the achievement that is based on the hard-working spirit (reso) as well as cultural principle of Buginese people "reso-pa temmangingi neletei pammase dewata sewa-E" which means that "successfulness that is blessed by God is achievable only through great effort." It implies that Buginese never 
gives up to a hard condition; they keep working hard, full of spirit, and persistent to attain what they want to achieve, including the female workers. It reflects that work ethic is interpreted as eagerness based on what they wish for in voluntary without being forced; besides, it also means how to define their attitude on particular problem they are facing. Buginese also has a high discipline in their work. It is revealed from the respondent's response that says agree and strongly agree when they are asked that a job must be finished soon, even today, and feel uncomfortable if they are late to accomplish the job that they are responsible for, from their supervisor.

Torajanese is bounded to traditional philosophy of their society until recent time; the traditional philosophical view does affect Torajanese in interpreting and doing something, including when they work in food and beverage small industry. Torajanese is also considered as hard working ethnicity. It is reflected on the number of responses which agree that "if I have sufficient inheritance/legacy for life, I will still work". It implies that they work hard to obtain income and to avoid losing face if one of their family members pass away but they are not able to arrange funeral ceremony based on their culture. In the traditional view of Torajanese ethnicity, it is a disgrace if the corpse of their family should be buried during late night since they are not able to arrange the traditional funeral ceremony as what the culture says. Therefore, Torajanese always focuses on working hard to be able to conduct traditional ceremony related to happiness expression (Rambu Tuka) and funeral ceremony [31].

\subsection{Conclusion}

\section{Conclusion And Suggestion}

The independent variables that significantly affect female workers productivity among Buginese, Makassarese, and Torajanese ethnic groups in food and beverage small industry in Makassar city are individual characteristics (health, work tenure, and work ethic), demographic factor (age), social-economics factor (wage) and work environment; meanwhile, the variables that do not cause significant influence are demographic factor (number of dependant), social-economics factor (education), and government policy. Further, there is a significant difference of the female worker productivity among Buginese, Makassarese, and Torajanese in the food and beverage small industry in Makassar city.

\subsection{Suggestion}

Based on the discussion and the conclusion, we provide the following suggestions:

1. PT Jamsostek should be more pro-active in socializing the social security program to the business owners/ entrepreneurs to help workers when the employers are willing to register those workers in at least one of the social security programs; moreover, the social security program will enhance worker productivity.

2. Those business owners/ entrepreneurs should register their workers in the social security program by providing certainty of the cash inflow sustainability and basic protection to fulfill basic needs of workers and their family; further, they should feel secure for their job at the workers' side and secure for their investment at the business owner's side to encourage the productivity achievement.

3. Female workers' potential is quite high; besides, the trend of female workers participation gets improved for year by year. Therefore, it is suggested that it needs better training system for female workers that is more comprehensive and more integrated, starting from the recruitment, placement, training, supervision, and development for female workers. Further, it also needs to consider female workers based on their nature and applicable work culture of each ethnicity.

\section{References}

[1] Guza, 2008. Himpunan Undang -Undang Tenaga Kerja. Penerbit Asa Mandiri Jakarta

[2] Indonesia Statistic/ Badan Pusat Statistik. 2010 Keadaan ketenagakerjaan Indonesia

[3] Indonesia Statistic/ Badan Pusat Statistik 2009 Keadaan Angkatan Kerja 2009

[4] Simanjuntak, Payaman. 2000. Kompensasi Efektif Untuk Produktivitas, Majalah Bagi Manajemen Dan Eksekutif No 139. PT Pustaka Binaan Pressindo ,Jakarta

[5] Bloom, D.E., Canning, D. and Sevilla, J. (2001), The Effect of Health on Economic Growth: Theory and Evidence, working paper no. 8587, National Bureau of Economic Research, Cambridge, $M A$

[6] Pindus, N., Koralek, R., Maritinson, K. and Trutko, J. (2000), Coordination and Integration ofWelfare and Workforce Development System, The Urban Institute, Washington, DC.

[7] Schultz, T. (2002), "Wage gains associated with height as a form of human capital", american Economic Review, Vol. 92 No. 2, pp. 349-53.

[8] Bloom ,D.E. And Canning, D (2003) The Health and Poverty Of Nation ; From Theory To Practice, Journal Of Human Development Vol 4 No 1, pp 827-55

[9] Llewelyn , (1999) Pengujian Model Regresi Untuk Pengukuran Produktivitas Tenaga Kerja .Kasus Industri Kecil Di Jawa Timur Jurnal Kewirausahaan Vol 1.,1-11

[10] Setiawati,Rike dan Sophia Amin (2001)., Faktor-faktor yang Mempengaruhi Produktivitas Tenaga Kerja Wanita pada Industri Kecil di Kota Jambi, Jurnal Pemberdayaan Perempuan, Vol.1, No.2, Kantor Menteri Negara Pemberdayaan Perempuan, Jakarta.

[11] Budhyani, 2008. Potensi Penrajin Wanita Dalam Pengembangan Kerajinan Uang Kepeng Di Kawasan Pariwisata Ubud Bali Jurnal Pengembangan Sains Dan Humaniora 2(1),43-55

[12] Semmaila, Baharuddin , 2008. Analisis Jam Kerja Dan Produktivitas Kerja Karyawan Etnis Bugis,Toraja Dan Makassar Pada 
Industri Kecil Di Kota Makassar.Disertasi,Program Pascasarjana Universitas Brawijaya

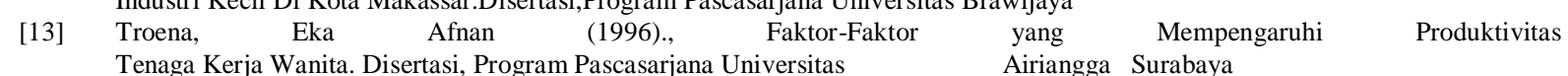

[14] Blaug M, (1972) Correlation Between Education and earning, Higher Education, Vol 1 No 1 pp $53-76$

[15] Card,D.(1999) The Causal Effect Of Education “ On Earnings, In Ashenfelter,O. And Car, D,Handbook Of Labor Economics Vol 3A Elsevier,Amsterdam ,pp 1801-63

[16] Pandey,Shanta dan Philip Young P 2007., Human Capital as Structural Vulnerability of US Poverty.Equal Opportunities International.Vol.26 no 1 pp $18-43$.

[17] Becker, G.S. (1993), Human Capital, 3rd ed., University of Chicago Press, Chicago

[18] Sakamoto,athur dan Chang Hwan Kim.,2008. Does Inequality Increase Productivity? :Evidence From U.S. Manufacturing Industries, 1976 to 1996. Vol 35 Number 1 85-114

[19] Badan Pusat Statistik 2007. Statistik Industri Besar Dan Sedang. Sulawesi Selatan

[20] Mattulada , 2009 Siri ’ Dan Pesse' Harga Diri Orang Bugis, Makassar, Mandar Dan Toraja, Penerbit Refleksi Makassar.

[21] Hamid, Abu,., 2009 Siri ' Dan Pesse' Harga Diri Orang Bugis, Makassar, Mandar Dan Toraja, Penerbit Refleksi Makassar.

[22] Umar, Hussein. 2001. Riset Sumberdaya Manusia Dan Organisasi, PT Gramedia Pustaka Utama, Jakarta

[23] Suma'mur (1991)., Higiene Perusahaan dan Kesehatan Kerja, Gunung Agung, Jakarta,

[24] Sumarsono,Sonny.2003. Ekonomi Manajemen Sumberdaya Manusia Dan Ketenagakerjaan. Graha Ilmu Yogyakarta

[25] Simanjuntak, Payaman J, 1985. Pengantar Ekonomi Sumber Daya Manusia, Penerbil Lembaga Fakultas Ekonomi Universitas Indonesia.

[26] Knapp David, 2007. The Influence Of Health On Labor Productivity; An Analysis of European Conscription Data. Departement of Economic The Osio State University.

[27] Ehrenberg, R.G. dan R.S. Smith (2003)., Moden Labor Economics, Theory and Public B Policy. Eighth Edition, Addison Wesley Longman, Inc., United States of America.

[28] Hasimoto, M And J. Raisin, 1999. Employment Tenure And Earnings Profile in Japan and The United State. American Economics Review vol 75 No 4 722-735.

[29] Fields, J. and E.N. Wollf, 2003. Interindustry wage Differensial and Gender Wage Gap. Industrial And Labor Relations Review, Vol 49, No 1; 105- 120.

[30] Ahmadin,2008., Kapitalisme Bugis. Pustaka Refleksi Makassar

[31] Salombe, 2009. Siri ' Dan Pesse' Harga Diri Orang Bugis, Makassar, Mandar Dan Toraja, Penerbit Refleksi Makassar.

[32] Smith ,J.P (1995) Healthy Bodies And Thick Wallets:the Dual Relation Between Health and Economic Status, Journal Of Economic Perspective vol 13 No 2 ,pp 145-66

[33] Poerwandari,Kristi,1995. Aspirasi Perempuan Bekerja dan Aktualisasinya: Dalam Ihromi T.O. (ED), Kajian Wanita Dalam Pembanguna, Yayasa Obor Indonesia Jakarta

[34] Wilbert, Gerald M, 2001. Leading in Economic Development. New York, Oxford University Press.

[35] SIagian, Sondang 2004. Kiat Meningkatkan Produktivitas. Penerbit PT Rineka Cipta, Jakarta

[36] Ekelund Robert B \& Hebert Robert F, 1997, A History Of Economic Theory Anda Method, Mc. Graw - Hill, Singapore.

[37] Ehrenberg, R.G. dan R.S. Smith (2000)., Moden Labor Economics, Theory and Public B Policy. Seven Edition, Addison Wesley Longman, Inc., United States of America.

[38] Choudhry,Misbah Tanveer, 2009. Determinants Of Labor Productivity: An Empirical Investigation Of Productivity Divergence. Department Of Economic And Econometrics University Of Groningen the Netherlands

[39] Soemarsono, Sonny. 2009., Teori Dan Kebijakan Publik Ekonomi Sumber Daya Manusia. Graha Ilmu , Yogyakarta

[40] Todaro,M dan Smith,S . 2006., Pembangunan Ekonomi . Penerbit Erlangga

[41] Grajek, M. (2001), Gender Pay Gap in Poland, Discussion Paper FS IV 01-13 01-13, Wissenschaftszentrum, Berlin.

[42] Keane, M.P. and Prasad, E.S. (2002a), Changes in the Structure of Earnings during the PolishTransition, Discussion Paper No. 496, IZA.

[43] Sedarmayanti, 2009. Tata Kerja Dan Produktivitas Kerja. Penerbit Mandar Maju, Bandung

[44] Abraham, Jean M, Anne Beeson Royalty. 2006. Healt Insurance And Labor Market Outcomes: Joint Decision -Making Within Household. Journal Of Public Economics 90. 1561-1577 